\title{
49. ANALYSIS OF NOISE ON DIGITAL SONIC LOG DATA AT LEG 120 SITES. DERIVED SYNTHETIC SEISMOGRAM AND CORRELATION WITH MCS DATA AT SITE 7471
}

\author{
Bernard Fritsch, ${ }^{2}$ Marc Munschy, ${ }^{2}$ and Fatmir Fezga ${ }^{2}$
}

\begin{abstract}
During Leg 120, weather conditions and time constraints restricted logging operations to Sites 747 and 750 ; only the seismic-stratigraphic combination was run at these sites. For some intervals, the sonic digital tool produced extremely noisy velocity logs that made interpretation of the data very difficult, even impossible. Three types of noise were observed: phase skipping, oscillations caused by noncompensated heave, and discrete aberrant velocity values. The heave-related oscillations recorded on the velocity logs were eliminated by deriving a simple model simulating the tool movement. The aberrant velocity values, essentially caused by failures in recording the signal from one of the two transmitters, were eliminated by inspection of the individual waveforms using an interactive software package. This software program was also used to pick the compressional arrival time. A composite velocity $\log$ accounting for all these corrections and complemented for the unlogged part of the hole with the core-measured velocities was used to derive a synthetic seismogram at Site 747 . The synthetic seismogram was correlated with a multichannel seismic reflection profile and the lithologic units, which allowed us to define four seismic sequences that could be identified with the K2-K3, P1-P2, PN1, and NQ1 sequences of the Raggatt Basin in the Southern Kerguelen Plateau.
\end{abstract}

\section{INTRODUCTION}

Holes $747 \mathrm{C}$ and $750 \mathrm{~A}$ were logged during Ocean Drilling Program (ODP) Leg 120. Because of bad weather conditions and time limitations, only the seismic-stratigraphic combination including the phasor induction tool (DITE), the natural gamma-ray spectroscopy tool (NGT), the digital sonic tool (SDT), and the multi-caliper tool (CAL), was run at both sites (Schlich, Wise, et al., 1989, "Explanatory Notes" chapter). The logged interval expands from 115 to $337 \mathrm{~m}$ below seafloor (mbsf) at Hole $747 \mathrm{C}$ and from 51 to $453 \mathrm{mbsf}$ at Hole $750 \mathrm{~A}$. Except for the first $100 \mathrm{~m}$ logged at Hole $750 \mathrm{~A}$, the wireline heave compensator did not work. Only the SDT logs seem to have been badly affected by this failure. The sonic logs were unreadeable on board over the intervals from 193 to $232 \mathrm{mbsf}$ and from 298 to 337 mbsf at Hole $747 \mathrm{C}$ (Schlich, Wise, et al., 1989 , "Site 747" chapter) and over the intervals from 145 to 170 mbsf and from 220 to $290 \mathrm{mbsf}$ at Hole $750 \mathrm{~A}$ (Schlich, Wise, et al., 1989, "Site 750 " chapter). The resistivity and the gamma-ray logs were of good quality, which permitted the Leg 120 scientists to identify log units along the two holes. To correlate the seismic reflectors observed on the multichannel seismic reflection (MCS) Profile MD 47-03 with the lithologic units at Site 747, a synthetic seismogram, restricted to the logged interval between 115 and 337 mbsf, was computed on board (Schlich, Wise, et al., 1989, "Site 747" chapter). This synthetic seismogram was derived from very poor quality data; moreover, it did not account for all the characteristics of the seismic source.

In this paper, we present a detailed analysis of the SDT measurements at Holes $747 \mathrm{C}$ and $750 \mathrm{~A}$, evaluate the noise level affecting the logging data, and finally compute corrected velocity logs. Using data from Hole 747C, an impedance log

\footnotetext{
${ }^{1}$ Wise, S. W., Jr., Schlich, R., et al., 1992. Proc. ODP, Sci. Results, 120: College Station, TX (Ocean Drilling Program).

2 Institut de Physique du Globe, Université Louis Pasteur, Laboratoire de Géophysique Marine (CNRS UA 323), 5 rue René Descartes, 67084 Strasbourg Cedex, France.
}

was built from the corrected velocity log, combined with and complementing the physical properties measurements. This impedance log was used to derive a synthetic seismogram that was correlated with Profile MD 47-03. At Hole 750A, the impedance $\log$ and the derived synthetic seismogram were also calculated and are described in Fritsch et al. (this volume).

\section{DESCRIPTION OF THE DIGITAL SONIC TOOL}

The SDT deployed during Leg 120 contains, from bottom to top, two transmitters ( $\mathrm{S} 1$ and $\mathrm{S} 2)$, spaced $0.61 \mathrm{~m}(2 \mathrm{ft})$ apart and two receivers (R1 and $\mathrm{R} 2)$, spaced $0.61 \mathrm{~m}(2 \mathrm{ft})$ apart.

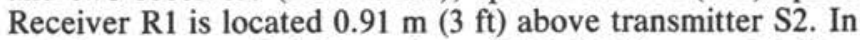
addition a group of eight receivers (RL1-RL8), spaced $0.15 \mathrm{~m}$ $(0.5 \mathrm{ft})$ apart, is located $2.43 \mathrm{~m}(8 \mathrm{ft})$ above transmitter S2 (Fig. 1). All the receivers record a full waveform, $5 \mathrm{~ms}$ long, with a sample rate of $10 \mu \mathrm{s}$. Only eight full waveforms were recorded during Leg 120 because of computer failures. The center frequency of the sonic signal is $12 \mathrm{kHz}$.

To produce a sonic log, the SDT measures transit times inside the formation surrounding the borehole. As the geometry of the SDT is precisely known, it is easy to calculate the velocities. On board, waveforms are recorded and a specific software program computes transit times. Compensation of the inclination of the tool along the borehole wall is achieved by memorizing the first transit time reading and averaging it with a second reading obtained after the probe has been pulled up a given distance (Fig. 2).

Using all combinations of the eight transit times, four slownesses were computed and named DT, DTL, DTLN, and DTLF. Each slowness, given in $s / m$, is based on four arrival time readings (Table 1 ). The velocity, in $\mathrm{m} / \mathrm{s}$, is directly obtained from the slowness. In this paper, DT, DTL, DTLN, and DTLF will refer to velocity values and not to slownesses.

\section{WAVE PROPAGATION IN BOREHOLES}

Biot (1952) has developed a theory of propagation of elastic waves in boreholes. Cheng and Toksöz (1981) and Paillet and White (1982) have described the different modes of propaga- 


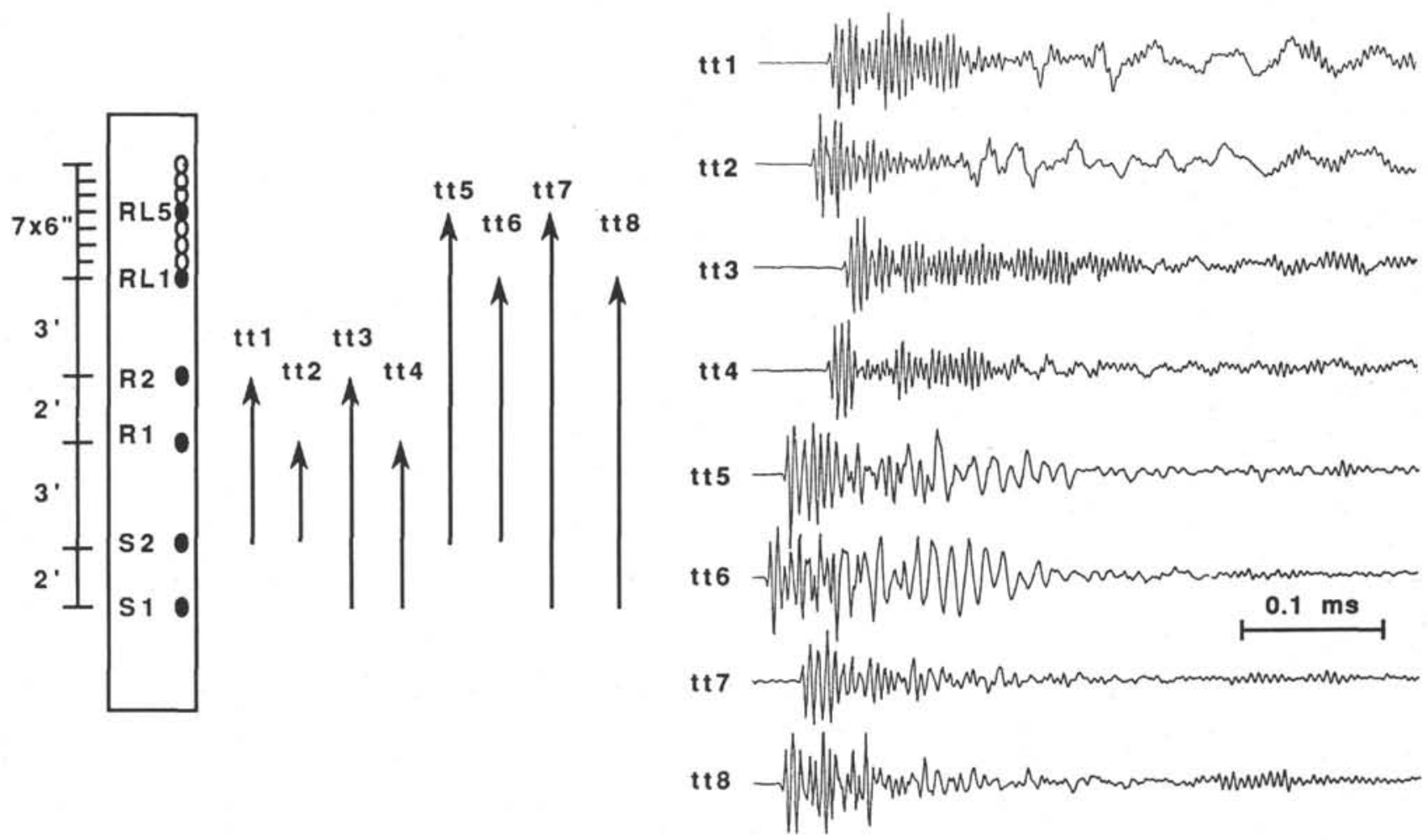

Figure 1. Diagram illustrating the digital sonic tool (SDT) configuration. Transmitters are S1 and S2; receivers are R1, R2, RL1, and RL5. The four shorter transit times ( $\mathrm{tt} 1-\mathrm{tt} 4)$ have different delay times than the four longer transit times ( $\mathrm{tt} 5-\mathrm{tt} 8$ ).

tion in boreholes. Acoustic wave packets are emitted, propagate in the fluid-filled hole, and interact with the formation, the borehole, and the borehole wall. The receivers record, in some cases, a refracted compressional wave followed by a refracted shear wave and/or a direct compressional wave that propagates in the fluid. Normal modes and Stoneley waves are also recorded. Compressional and shear arrival times depend on the physical properties of the rock formation. Normal modes are sensitive to the borehole radius as well as the rigidity of the rock formation. Stoneley waves are most sensitive to the borehole radius and to the borehole wall rugosity, which may be related to the fracturing of the rock formation in hard rock such as basalt (Paillet and White, 1982).

In hard formations, such as in fresh basalt or limestones, compressional, shear, and other arrival times are well defined. In soft formations, with velocities ranging from 1500 to 2000 $\mathrm{m} / \mathrm{s}$, the different waves can be more difficult to identify (Winbow, 1988) and the refracted waves can be missed. Cheng and Toksöz (1981) provide a more detailed description of the effect of rock type on sonic waveforms.

\section{DESCRIPTION OF THE NOISE}

Sonic data at Holes $747 \mathrm{C}$ and $750 \mathrm{~A}$ are badly affected by noise. At some depths, records are so noisy that the signal of the transmitters cannot be recognized. The two velocities DTLF and DTLN, determined from the longest transit time, appear to be much more affected by the noise than the two other velocities and will not be used in this paper. Three types of noise were identified (Fig. 3):

Type 1: signal decay or phase skipping that is easy to detect and to correct;

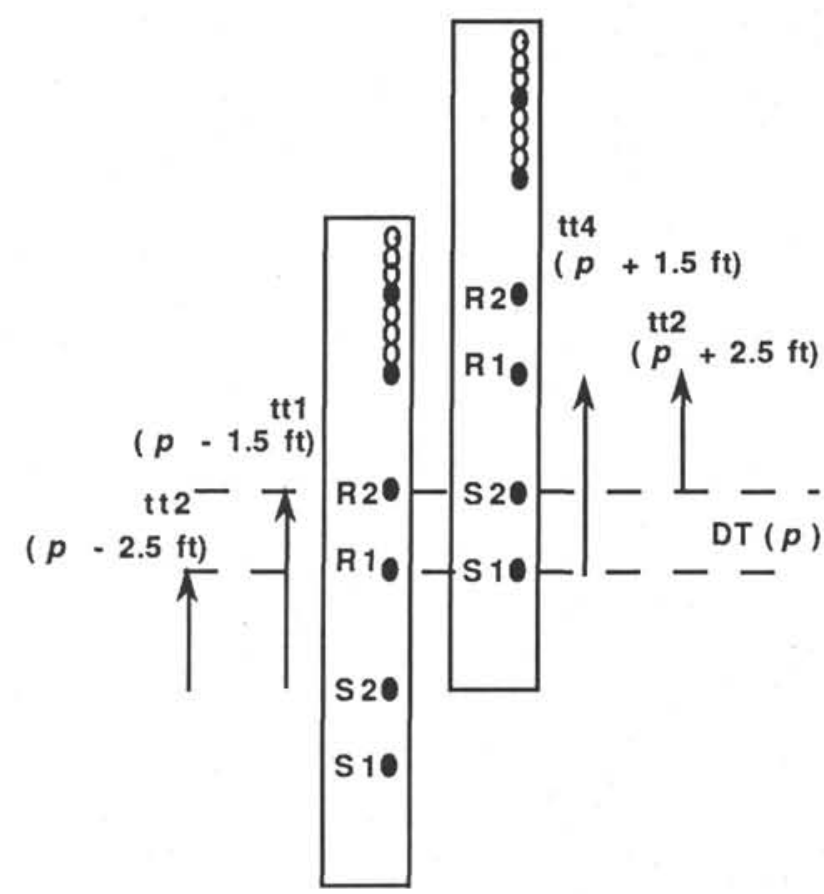

Figure 2. Principle of SDT slowness measurement at depth $p$ corrected for the inclination of the tool. The first set of transit times ( $\mathrm{tt} 1-\mathrm{tt} 4)$ are averaged with a second set of transit times ( $\mathrm{tt} 2-\mathrm{tt} 4)$ obtained after the probe has been pulled up by $5 \mathrm{ft}$. 
Table 1. Slownesses computed from four transit time readings.

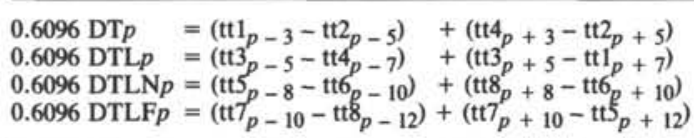

Notes: $\mathrm{tt}_{\mathrm{j}}=$ transit time corresponding to the $\mathrm{j}^{\text {th }}$ waveform (Fig. 1). Index $p+$ $i=(p+i)^{\text {th }}$ depth sample.
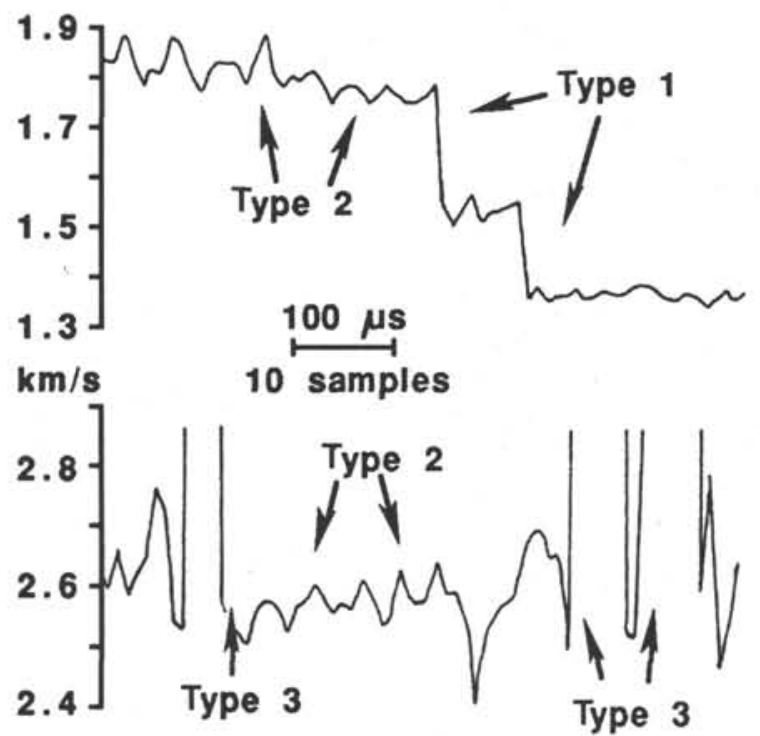

Figure 3. Noise types observed on SDT velocity curves. Type 1 noise: phase skipping. Type 2 noise: variations of velocity related to the tool movement. Type 3 noise: aberrant velocity values.

Type 2: oscillations of transit times with a periodicity of about $1 \mathrm{~m}$ that cause apparent velocity variations of $150-200$ $\mathrm{m} / \mathrm{s}$; and

Type 3: isolated peaks that correspond to one or three values with aberrant amplitude.

\section{Type 1 Noise}

Type 1 noise was encountered once in Hole 747C (at 170 mbsf) and four times in Hole 750A (134, 145-170, 220-245, and $375-410 \mathrm{mbsf}$ ). This type of noise was removed on board (Schlich, Wise, et al., 1989, "Site 747" and "Site 750" chapters). Type 2 noise affects all the SDT logs, and Type 3 noise was clearly observed between 210 and $240 \mathrm{mbsf}$ at Hole $747 \mathrm{C}$ and affected largely the lower part of the Hole $750 \mathrm{~A}$. These two last types of noise could not be removed on board during Leg 120.

After completing Leg 120, Schlumberger reprocessed the SDT signals. The resulting velocity $\log$ at Hole $750 \mathrm{~A}$ is globally of good quality, but at Hole $747 \mathrm{C}$ the velocity values in the basalt are too small compared to the core velocity determinations. The sediment/basalt contact is also not well defined on this later velocity log.

\section{Type 2 Noise}

All logging curves show oscillations along the logged intervals, with periodicities ranging from 1 to $5 \mathrm{~m}$. On SDT logs this noise corresponds to an amplitude of $20 \mu \mathrm{s}$ on transit times or $150-200 \mathrm{~m} / \mathrm{s}$ on velocities. The tension log corresponds to the tension measured on the cable during the logging operation and shows regular variations of $500 \mathrm{lb}$ with a period of $1 \mathrm{~m}$ at Hole
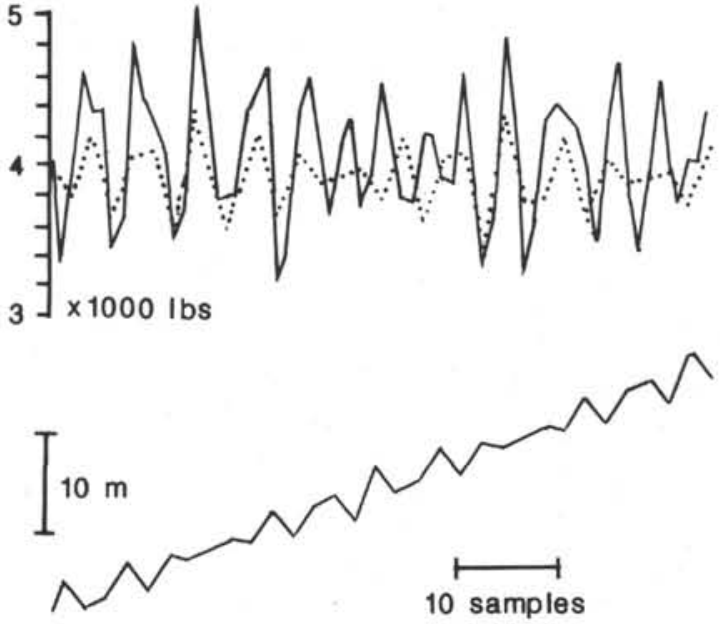

Figure 4. Tool string movement during pull up. Top, proposed model (dashed line) compared with the tension curve (solid line). Bottom, movement of the toolstring resulting from modeling.

747C (Fig. 4). These variations have the same period as the ship motions, and, because such periods are seen on all other logs, we have related these variations to the ship motions.

During logging at Hole $747 \mathrm{C}$, winds exceeded $50 \mathrm{kt}$ and confused swells caused the ship to have a vertical heave of $3-4 \mathrm{~m}$, with a period of 5-6 s; this strong heave caused the compensator to "trip out" (Schlich, Wise, et al., 1989, "Site 747" chapter). At Hole $750 \mathrm{~A}$ the heave compensator only operated for the first $100 \mathrm{~m}$ of logging; in this interval, the tension curve showed small oscillations that did not affect the other logging curves.

Movement of the logging probe in the borehole was obtained by combining the upward displacement of the logging cable with the ship heave. The ship heave was modeled by a sinusoidal function of $3-\mathrm{m}$ amplitude and periods ranging from 2 to $6 \mathrm{~s}$. The cable velocity was assumed to be constant (7 $\mathrm{cm} / \mathrm{s}, 850 \mathrm{ft} / \mathrm{hr})$ and the sampling rate was $0.15 \mathrm{~m}(0.5 \mathrm{ft})$ or 2 $\mathrm{s}$; we neglected to account for the elasticity of the cable. The probe movement computed with these parameters has the same phases as the measured tension curve (Fig. 4). The amplitudes of the signal were not modeled because we did not know the weight of both the cable and the logging probe. This model shows that there is a maximum of six samples $(0.9 \mathrm{~m})$ between the first and last reading at a given depth. If we suppose that the tool is at a particular depth, its real position is, in fact, centered somewhere on a $0.9-\mathrm{m}$ interval. Consequently, uncompensated ship heave decreases the vertical resolution to $0.9 \mathrm{~m}$. Thus, data are oversampled and must be averaged. Type 2 noise is filtered by convolving the logging curves with a triangle function of seven samples (a weighted centered running average was applied).

\section{Type 3 Noise}

Isolated velocity peaks always correspond to Type 3 noise and never to the occurrence of a thin layer ( $\leq 0.3 \mathrm{~m}$ thick) with high velocity: all transit times would be affected by the high velocity of the thin layer; this was not observed. Type 3 noise was caused by an erroneous reading of one arrival time; and, from Table 1 , we see that an erroneous transit time $\mathrm{tt}_{\mathrm{j}}$ at depth $p$ causes a positive or negative jump of velocity at one or two specific depths (Table 2), as observed in the data. Every time Type 3 noise was encountered, it affected three successive samples of one $\mathrm{tt}_{\mathrm{j}}$. 
Table 2. Occurrence of velocity jumps on DT and DTL caused by an erroneous transit time reading $\mathrm{tt}_{\mathrm{j}}$.

\begin{tabular}{lcccc}
\hline & \multicolumn{1}{c}{$\mathrm{t} 1$} & $\mathrm{tt} 2$ & $\mathrm{tt} 3$ & $\mathrm{tt} 4$ \\
\hline DT & $(+) p+3$ & $(-) p+5$ & None & $(+) p-3$ \\
DTL & $(-) p-7$ & $\begin{array}{c}(-) p-5 \\
\text { None }\end{array}$ & $\begin{array}{l}(+) p+5 \\
(+) p-5\end{array}$ & $(-) p+7$ \\
& & & $(+) p+7$ & \\
\hline
\end{tabular}

Notes: An error on $\mathrm{tt} 1$ on the $p^{\text {th }}$ sample caused a positive jump $(+)$ on DT at the $(p+3)^{\text {th }}$ sample and a negative jump - on DTL at the $(p-7)^{\text {th }}$ sample.

Type 3 noise was easily removed except in two intervals at Hole 747C (188-228 and 288-337 mbsf), where too many aberrant transit time readings occurred (Figs. 5 and 6). In these cases, a low-frequency with high-amplitude signal was superimposed on the waveforms (Fig. 7) emitted by Source S1. The low-frequency noise looks like background noise overamplified during the recording of a waveform. A misfire at Source S1 is mainly responsible for Type 3 noise.

It was not possible to filter this low-frequency noise without losing the first arrival on the waveform; we removed type 3 noise by using transit time readings related only to Transmitter S2 (tt1 and tt2). The corresponding "noncompensated" velocity logs are shown in Figures 5 and 6; aberrant transit time readings are replaced by the mean of the two neighboring values. Although these logs are not corrected from the tool inclination, they appear better than the raw logs and the proposed Schlumberger logs, especially at Hole 750A, from 170 to 220 mbsf, where the Schlumberger log shows a lot of velocity variations not seen on both the raw velocity log and our "noncompensated" velocity log. However, at Hole $747 \mathrm{C}$, the derived velocities are too low $(\leq 1500 \mathrm{~m} / \mathrm{s})$ in some places of the 188-228-mbsf interval, suggesting a bad arrival time picking.

To study these zones of abnormal low velocity values, a software package that displays the waveforms on a computer graphic screen was developed to pick the compressional arrival times manually. The "interactive" DT and DTL curves, shown in Figure 5, are computed from four arrival times. To test the validity of the velocity determination, we have expanded the computation to the entire logged interval; the corresponding DT and DTL velocity logs fit much better with the physical properties measurements. With the exception of four specific zones where DT is either lower or higher than DTL, the two logs are very similar:

1. From 115 to $175 \mathrm{mbsf}$, DT velocity values are $\leq 1500$ $\mathrm{m} / \mathrm{s}$, whereas DTL velocity values are higher. At these depths, the borehole diameter is $37-38 \mathrm{~cm}$, and the formation velocity, deduced from the DTL $\log$, is about $1600 \mathrm{~m} / \mathrm{s}$; with these parameters the critical offset (minimal offset to have a compressional refracted wave) is near the first receiver (R1). If the offset of the receiver is slightly longer than the critical offset the arrival time difference between the formation compressional wave and the fluid compressional wave should be only $40 \mu \mathrm{s}$ (four samples) for the 3 -ft $(0.91 \mathrm{~m})$ transit time, $60 \mu \mathrm{s}$ (six samples) for the 5 - $\mathrm{ft}(1.52 \mathrm{~m})$ transit time, and $90 \mu \mathrm{s}$ (nine samples) for the 7 - $\mathrm{ft}(2.13 \mathrm{~m})$ transit time. Thus, it is obvious that the formation compressional arrival time should be read on the long spacing measurement (DTL).

2. From 210 to 220 mbsf, the same situation is encountered with DT $\leq 1500 \mathrm{~m} / \mathrm{s}$.

3. From 220 to $228 \mathrm{mbsf}$ and from 297 to $305 \mathrm{mbsf}$, the DTL velocity values are too low in comparison with the DT velocity values. These differences are explained at both intervals by errors on the $\mathrm{tt} 3$ readings that correspond to the longest transit time $(7 \mathrm{ft}, 2.13 \mathrm{~m})$. The compressional wave recognized on the full waveforms has a very low amplitude compared with other waves, and thus cycle skipping may affect the readings. The compressional wave attenuation in this part of the hole is higher, possibly because of formation fractures, inhomogeneous sections, or rough borehole wall conditions.

\section{Velocity Log Used for the Synthetic Seismogram}

As shown previously, the "interactive" DT and DTL logs give the best estimation of the formation velocity. However, depending on the depth, we have chosen either DT or DTL logs. From 115 to $175 \mathrm{mbsf}$ and from 210 to $220 \mathrm{mbsf}$, the DTL velocity was used; from 220 to 228 mbsf and from 297 to 305 mbsf, the DT velocity was used. Outside of these intervals, the DT and DTL logs are identical. The corresponding "composite" velocity log agrees well with the log unit subdivisions (Schlich, Wise, et al., 1989, "Site 747" chapter). Outside of the 115-337 mbsf interval, we completed the velocity log with velocity measured on cores and corrected from decompaction using porosity values (Fritsch et al., this volume). The exponential variation of porosity with depth (porosity $=$ measured porosity $\cdot \exp [-\mathrm{K} \cdot \mathrm{depth}])$ was used with a formation coefficient $\mathrm{K}$ of 0.0004 for the upper interval (0-115 mbsf) and of 0.0 for the basalts in the lower interval (337-350 mbsf). We identified this resulting velocity log as the "composite velocity $\log$," and we used the results to compute the synthetic seismogram.

\section{DESCRIPTION OF DT AND DTL LOGS AT SITE 747}

Taking into account the composite velocity log, we are able to explain more accurately the different log units (Fig. 8) defined by the scientists on Leg 120 (Schlich, Wise, et al., 1989, "Site 747" chapter, pp. 139-143).

\section{Log Unit 1}

Between 115 and $188 \mathrm{mbsf}$, velocity increases slowly and smoothly from 1600 up to $2000 \mathrm{~m} / \mathrm{s}$. This increase in velocity may indicate a decrease in porosity caused by the compaction of sediments.

\section{Log Unit 2}

Between 188 and 228 mbsf, three low-velocity intervals were recognized (188-198, 208-212, and 217-220 mbsf); they are associated with anomalous values of resistivity and gamma ray. Between 220 and 228 mbsf, DTL velocities are too low because they are affected by Type 3 noise. Log Unit 2 is divided in two subunits. The upper part, between 188 and 200 mbsf, is characterized by a mean velocity of $1700-1900$ $\mathrm{m} / \mathrm{s}$, high resistivity, and high gamma-ray values. The lower part, between 200 and 228 mbsf, has a mean velocity of 2300 $\mathrm{m} / \mathrm{s}$ and is interbedded by two layers (208-212 and $217-220$ $\mathrm{mbsf}$ ); the lower velocity was estimated at $1800-2000 \mathrm{~m} / \mathrm{s}$. The first layer is associated with high gamma-ray values and a resistivity peak, the second with lower gamma-ray values and low resistivity. The transition between Log Units 2 and 3 does not correspond to a major velocity change.

\section{Log Unit 3}

Between 228 and 297 mbsf, velocity increases slowly with depth, suggesting compaction of sediments. At 245 mbsf, DT and DTL velocity logs differ (Fig. 5); this difference may be related to heterogeneities in the chalk section.

\section{Log Unit 4}

The sediment/basalt contact was reached by drilling at 297 mbsf. At this depth, an abrupt change of velocity from 2800 to 

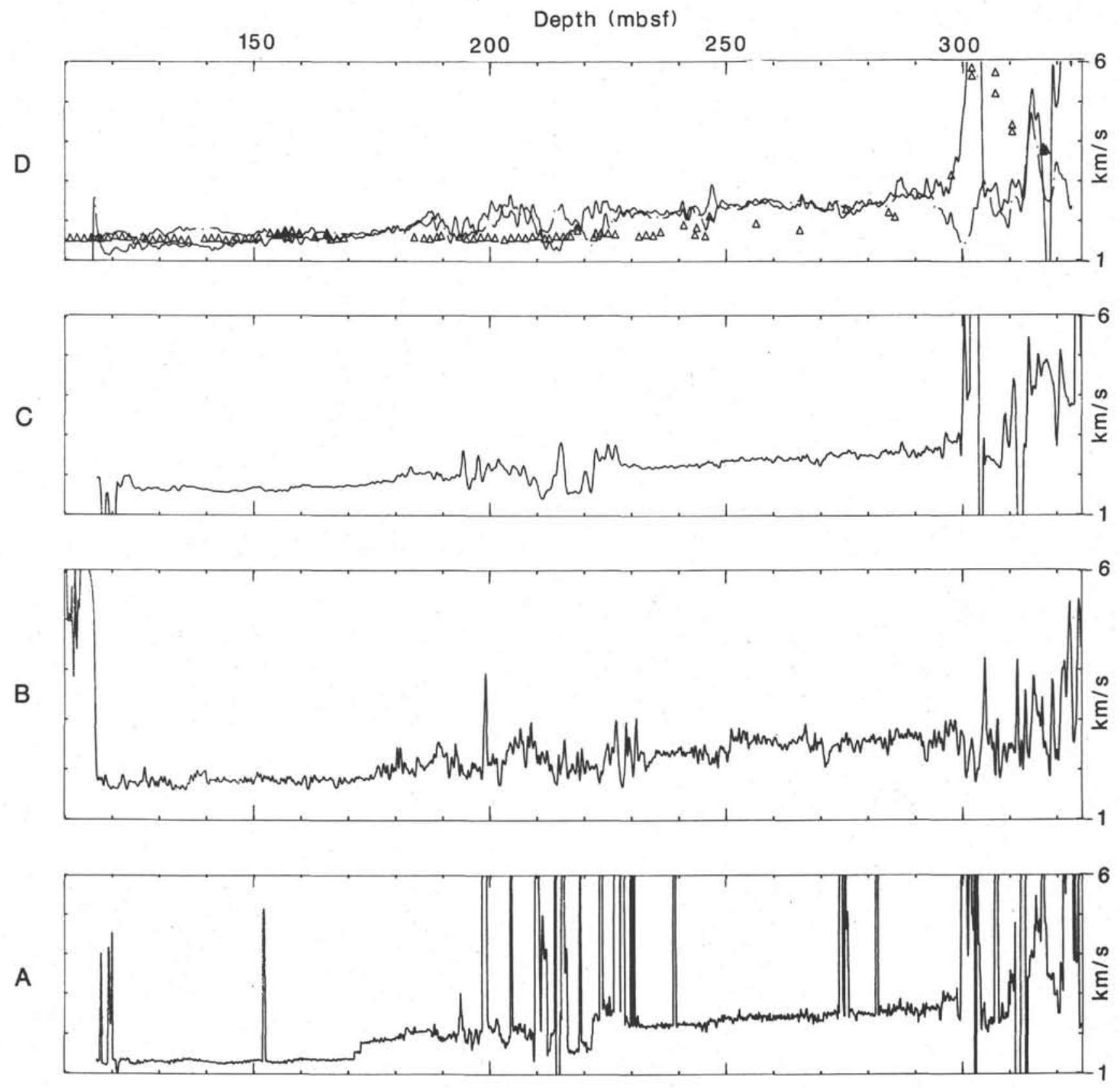

CAL

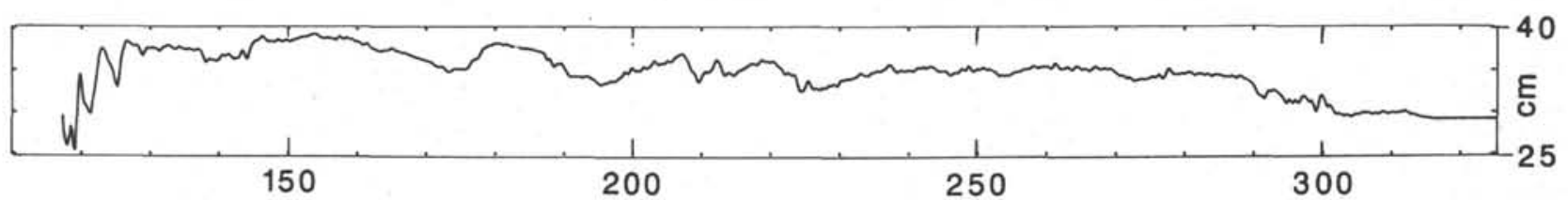

Figure 5. Velocity logs at Site 747. CAL = borehole diameter from caliper. A. Raw DT velocity logs. B. Corrected velocity log proposed by Schlumberger. C. "Noncompensated" velocity log, computed with tt1 and tt2 only. D. "Interactive" DT and DTL velocity logs, computed with the interactive software. Triangles correspond to core velocity measurements. 

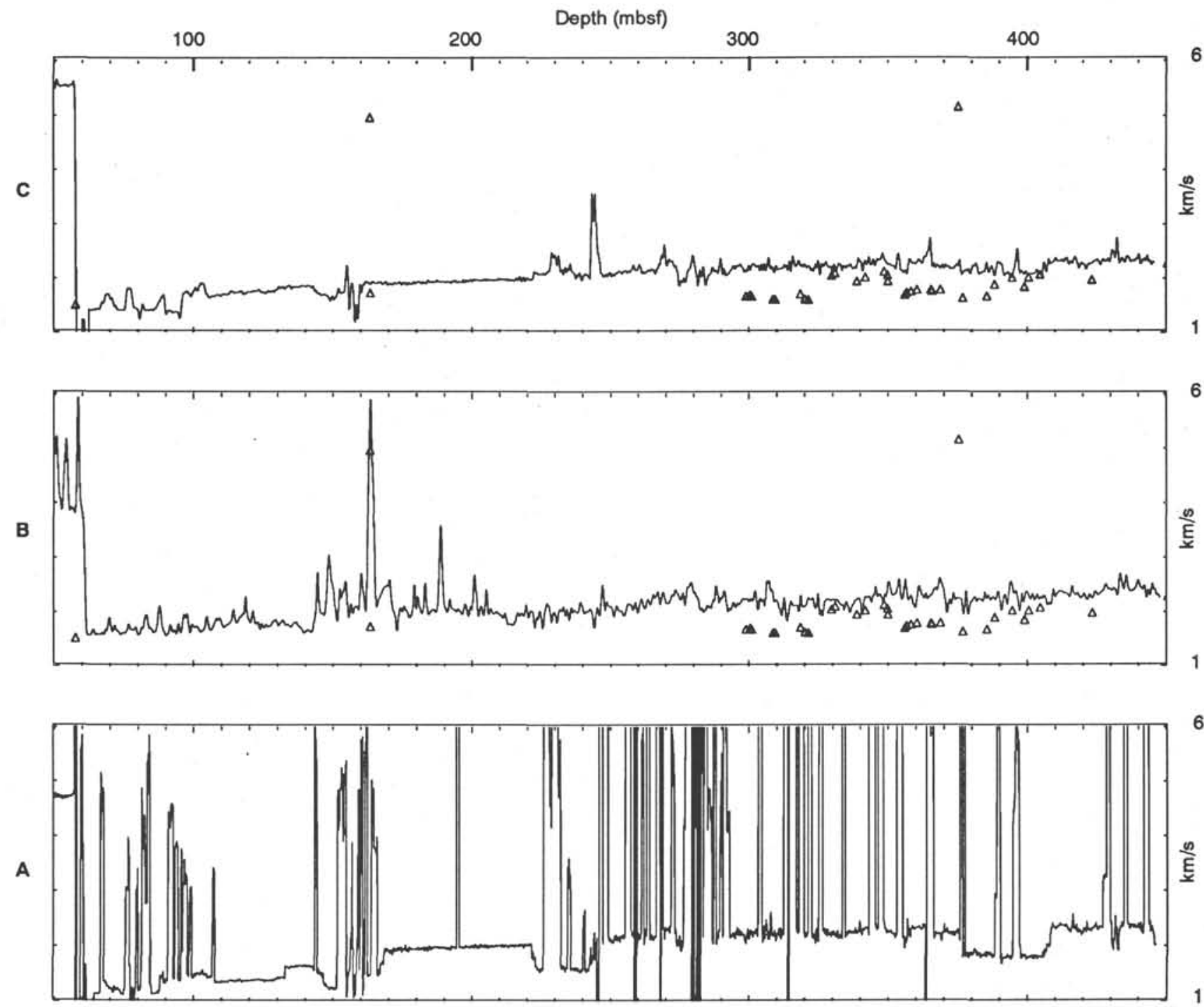

6

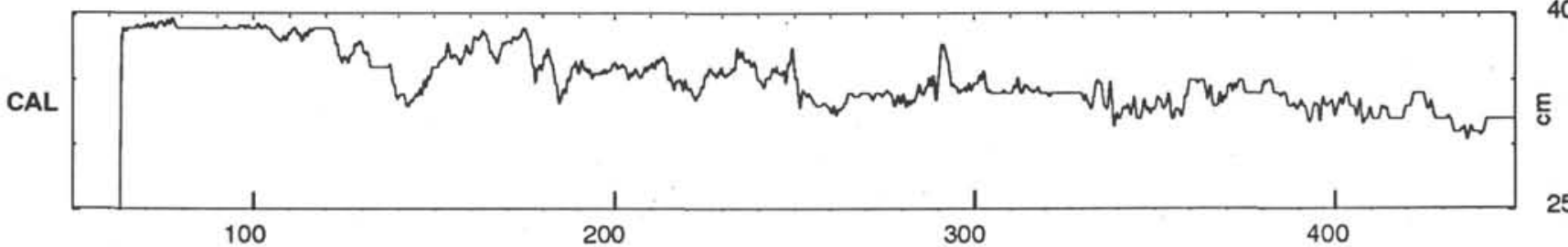

Figure 6. Velocity log at Site 750. CAL = borehole diameter from caliper. A. Raw DT velocity logs. B. Corrected velocity log proposed by Schlumberger. C. "Noncompensated" velocity log, computed with $\mathrm{tt} 1$ and $\mathrm{tt} 2$ only. Triangles correspond to core velocity measurements.

more than $6000 \mathrm{~m} / \mathrm{s}$ was observed. The velocity values obtained between 297 and 306 mbsf (log Subunit 4A) are indicative of basalt velocity values, but as they exceed $6000 \mathrm{~m} / \mathrm{s}$ they are certainly overestimated. The large discrepancy between the DT and DTL logs is indicative of highly fractured basalts. Between 306 and 320 mbsf (log Subunits 4B and 4C), the mean velocity is about $2700-2800 \mathrm{~m} / \mathrm{s}$; this interval shows a high velocity $(4000-5000 \mathrm{~m} / \mathrm{s})$ between 313 and $318 \mathrm{mbsf}(\log$ Subunit 4C) that corresponds to massive basalt flows (Cores 120-747C-12R-1 and -13R-1) emplaced between brecciated basalts with clays. Between 320 and 337 mbsf (log Subunit
4D), a velocity of $4000-5000 \mathrm{~m} / \mathrm{s}$ indicates that the formation is mainly composed of massive basalt flows.

\section{SYNTHETIC SEISMOGRAM AT SITE 747}

A synthetic seismogram was computed and compared with the MCS Profile MD 47-03 crossing Site 747. The Marion Dufresne Cruise 47 used a flexichoc fired every $50 \mathrm{~m}$ and a 24-channel streamer to acquire seismic data at a 4-ms sample rate. The data were normal-move-out (NMO) corrected, stacked ( 24 folds), band-pass filtered $(12-50 \mathrm{~Hz})$, and averaged on a running window (AGC) before being plotted 

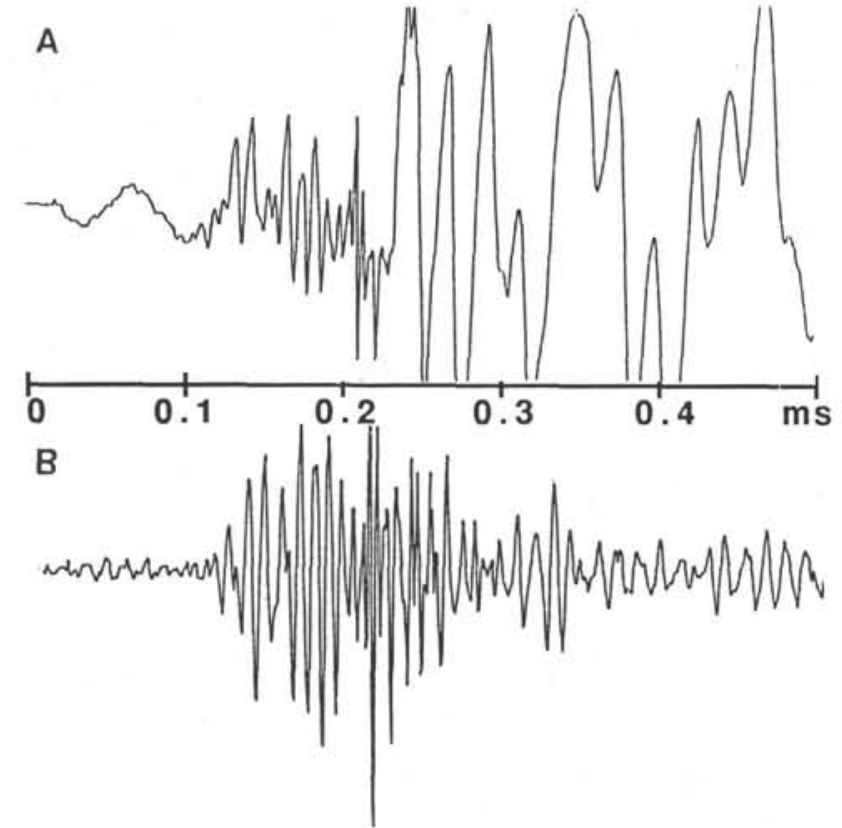

Figure 7. Low-frequency noise superimposed on the waveform. A. Raw waveform. B. High bandpass-filtered waveform with a cutoff frequency of $7 \mathrm{kHz}$.

(Schlich et al., 1988). To compute the synthetic seismogram, we used a program based on the reflection coefficient method (Sheriff, 1977; Badley, 1985): a series of reflection-coefficients are convolved with the seismic source signals. The accuracy of the synthetic seismogram is directly related to the number and length of the depth intervals used for the convolution. Thus, to avoid the introduction of fictitious steps, we have (1) interpolated the composite velocity log, the discrete bulk density, the grain density and the porosity values with a cubic spline; (2) resampled the curves assuming that the physical parameters were constant along each depth interval; and (3) corrected the bulk density from the compaction using the grain density and the porosity measurements. The impedance log was calculated, expressed in two-way traveltime (twt) using the velocity values, and resampled at a sample rate of 2 $\mathrm{ms}$. To calculate the reflection-coefficient series, the wavelet used was the far-field signature of the source recorded during a fire test (Fig. 9). The seismic signal, sampled at a time rate of $2 \mathrm{~ms}$, was convolved with the reflection-coefficient series. Finally, the synthetic seismogram obtained was band-pass filtered $(12-50 \mathrm{~Hz})$. No amplitude gain control was done on the synthetic seismogram.

\section{CORRELATION WITH MULTICHANNEL SEISMIC SECTIONS}

Only two distinct seismic sequences were identified at Site 747 (Schlich, Wise, et al., 1989, "Site 747" chapter): the boundary between the two sequences was located at 0.22 $0.24 \mathrm{~s}$ twt below seafloor and the basement reflector at $0.33-0.37 \mathrm{~s}$ twt below seafloor on Profile MD 47-03. Using the synthetic seismogram, we correlated the lithologic units recognized at Site 747 with the different seismic reflectors. In the description given below, we shall try to use the seismic sequence nomenclature defined by Schlich, Wise, et al. (1989) and Coffin et al. (1990) in the Raggatt Basin (Fig. 10 and Table 3).

The lowest high-amplitude wavelet observed on the synthetic seismogram at $0.32 \mathrm{~s}$ twt corresponds to the sediment/ basement contact at 297 mbsf. The wavelet at $0.30 \mathrm{~s}$ twt $(270$ mbsf) corresponds to the top of a thin layer with a velocity of $2.8 \mathrm{~km} / \mathrm{s}$ at $285 \mathrm{mbsf}$, but it is not associated with a clearly defined reflector on the seismic profile. The thickness of this layer (about $20 \mathrm{~m}$ ), similar to the seismic resolution, explains the variability observed for the basement reflector along the seismic profile.

The reflector at $0.23 \mathrm{~s}$ twt corresponds to a depth of 190 mbsf in the volcaniclastic sediments of lithologic Unit III. On the synthetic seismogram, the corresponding wavelet is more complex; at $0.24 \mathrm{~s}$ twt ( $205 \mathrm{mbsf})$, a wavelet is superimposed and corresponds to the bottom of the volcaniclastic sediments at Hole 747C (Core 120-747C-5R; Schlich, Wise, et al., 1989). The reflector at $0.23 \mathrm{~s}$ twt cannot be associated with the top or bottom of lithologic Unit III. It corresponds to an unconformity (Schlich, Wise, et al., 1989, "Site 747"' chapter) dated as late Maestrichtian to early Paleocene and, therefore, is contemporaneous with the major tectonic event that formed the $77^{\circ} \mathrm{E}$ Graben (Munschy et al., this volume). This event is also recorded at Site 748 in the Raggatt Basin and is synchronous with the K3/P1 boundary (Fritsch et al., this volume). The reflectors between $0.23 \mathrm{~s}$ twt and the basement reflector, dated as Maestrichtian to Santonian, can be associated with the K2 and $\mathrm{K} 3$ sequences in the Raggatt Basin.

Between $0.15-0.19$ and $0.23 \mathrm{~s}$ twt, the synthetic seismogram is different from the seismic profile. Nevertheless, there are three reflectors on the seismic profile and three maxima and minima on the synthetic seismogram. The velocity distribution between 140 and 190 mbsf can explain these differences: the observed velocity inversions probably mask the reflection at $0.2 \mathrm{~s}$ twt on the seismic profile. The reflector at $0.19 \mathrm{~s}$ twt ( $150 \mathrm{mbsf}$ ) is located $9 \mathrm{~m}$ above the top of lithologic Subunit IIB and is dated as lower Oligocene. It corresponds to an unconformity defined by toplaps westward of Site 747 (Munschy et al., this volume). The reflector at $0.2 \mathrm{~s}$ twt is associated with the minima at $0.22 \mathrm{~s}$ twt and, thus, to the top of lithologic Subunit IIC at 180 mbsf, dated as Danian. It also corresponds to an unconformity. Thus, the sequence between 0.19 and $0.23 \mathrm{~s}$ twt is associated with Sequences $\mathrm{P} 1$ and $\mathrm{P} 2$ in the Raggatt Basin.

At $0.15 \mathrm{~s}$ twt (125 mbsf), a significant reflector is observed on the seismic profile; the corresponding wavelet results from a velocity increase at $125 \mathrm{mbsf}$. The reflector at $0.15 \mathrm{~s}$ twt is associated with the PN1/NQ1 sequence boundary in the Raggatt Basin.

Between 0.03 and $0.13 \mathrm{~s}$ twt, the synthetic seismogram is quite different from the seismic profile. On the seismic profile, the high-amplitude reflector at $0.06 \mathrm{~s}$ twt does not correspond to a well-defined wavelet on the synthetic seismogram. The high-amplitude reflector at $0.03 \mathrm{~s}$ twt $(30 \mathrm{mbsf})$ is associated with the top of lithologic Unit II.

\section{CONCLUSIONS}

Because of severe time restrictions, logging during Leg 120 was only conducted at Sites 747 and 750 and furthermore was restricted to the seismic-stratigraphic combination (DITE/ SDT/NGT/CAL). Bad weather conditions prevailed during most of the logging operations, and breakdown of the heave compensator induced important noise that mainly affected the sonic digital tool and limited the interpretation of the velocity data and the correlation studies with the MCS profiles and the lithologic sections.

Three types of noise were observed. Phase skipping was easily removed by adjusting the gain control. Erratic tool movements were modeled by a sinusoidal function and eliminated by averaging seven consecutive samples. A malfunction of one of the two transmitters introduced discrete aber- 

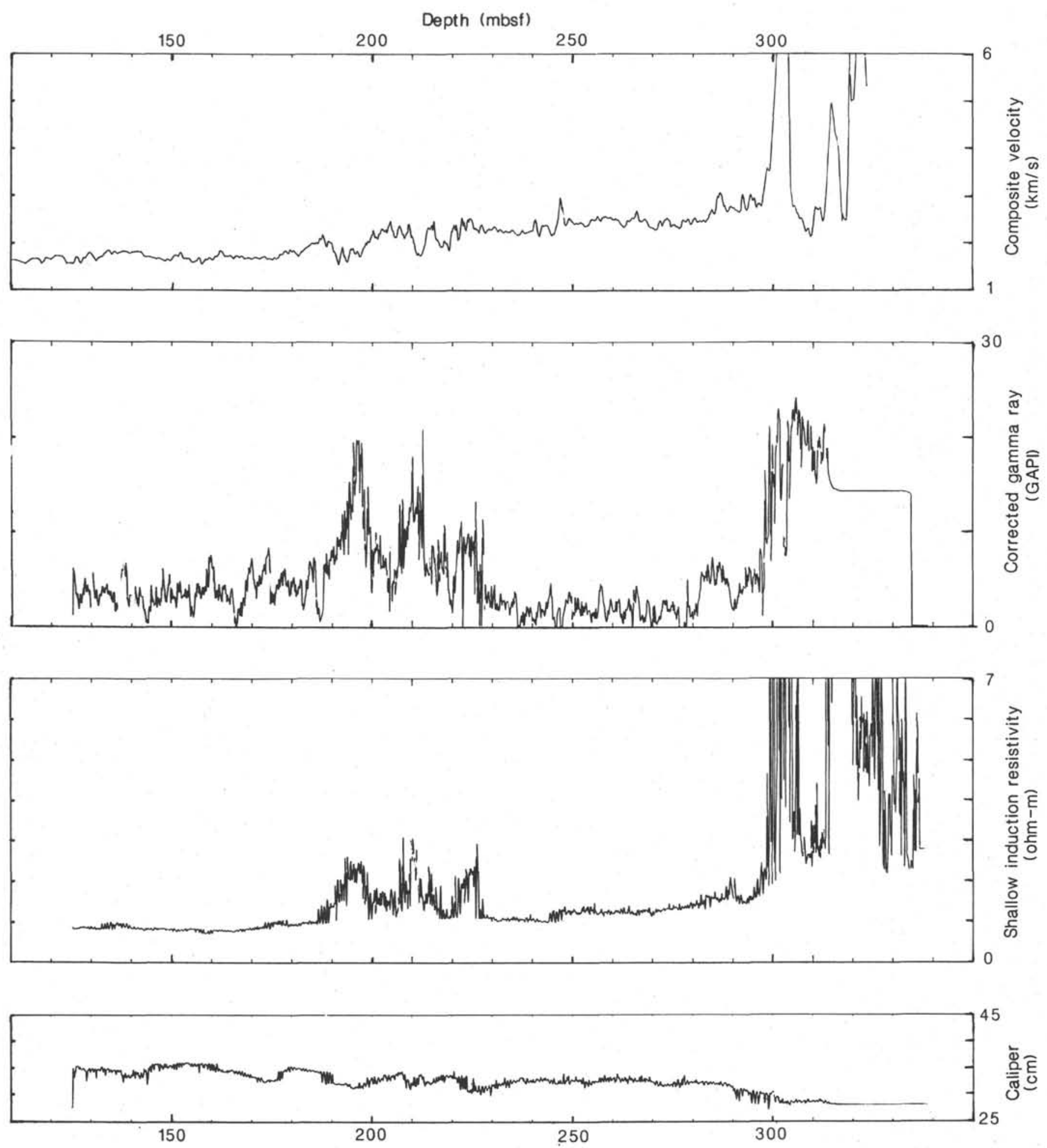

Figure 8. Composite velocity log at Site 747 compared with one of the resistivity logs (SFLU), the gamma ray log (NGT), and the caliper log (CAL). 

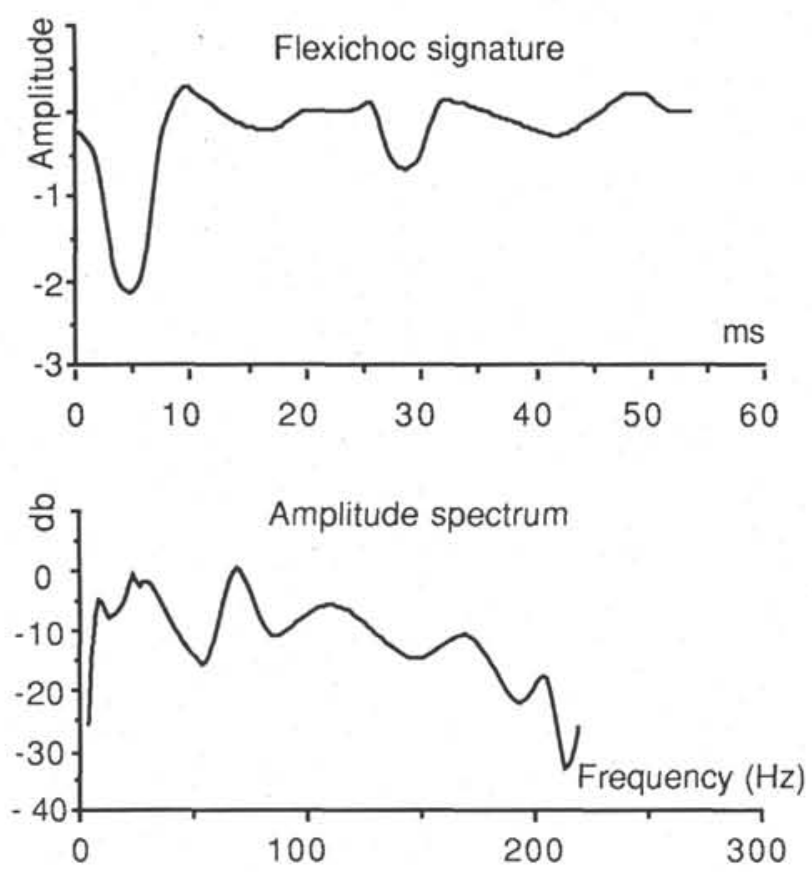

Figure 9. Seismic signature and amplitude spectrum of a flexichoc (from Magneville, 1971). This signal is a far-field signal recorded during a fire test.

rant velocity values. This noise was reduced by using the transit times from only one transmitter and was almost removed by using an interactive software package to pick out the compressional arrival time.

At this stage, it was possible to construct a composite velocity log combining the "interactive" DT and DTL velocities. At Site 747, this composite $\log$ was extended to the entire hole by taking into account the core velocity measurements corrected from compaction. A synthetic seismogram was derived, used to identify the reflectors observed on MCS Profile MD 47-03, and correlated with the different lithologic units recognized at the site. Four seismic sequences were distinguished, dated, and correlated with the different sequences observed in the Raggatt Basin (K2-K3, P1-P2, PN1, and NQ1).

\section{ACKNOWLEDGMENTS}

M. Munschy thanks the Ocean Drilling Program for inviting him to participate on Leg 120 aboard the JOIDES
Resolution. The authors are grateful to E. Pratson and N. Blackburn for their contribution on board and for providing the reprocessed Schlumberger data. The authors thank R. Schlich for his contribution to this paper and are grateful to E. Barbu, D. Moos, and an anonymous reviewer for their critical reviews and comments. We also thank Monique Blanck for drafting the figures. We are grateful to Territoire des Terres Australes et Antarctiques Françises for their support on board Marion Dufresne Cruise 47. This work was supported by the Centre National de la Recherche Scientifique (ODP-France).

\section{REFERENCES}

Badley, M. E., 1985. Data preparation and preliminary studies. In Badley, M. E. (Ed.), Practical Seismic Interpretation (Vol. 6): Boston (International Human Resources Development Corp.), 157-186.

Biot, M. A., 1952. Propagation of elastic waves in a cylindrical bore containing a fluid. J. Appl. Phys., 23:997-1005.

Cheng, C. H., and Toksöz, M. N., 1981. Elastic wave propagation in a fluid-filled borehole and synthetic acoustic logs. Geophysics, 46:1042-1053.

Coffin, M. F., Munschy, M., Colwell, J. B., Schlich, R., Davies, H. L., and Li, Z. G., 1990. Seismic stratigraphy of the Raggatt Basin, Southern Kerguelen Plateau: tectonic and paleoceanographic implications. Geol. Soc. Am. Bull., 102:563-579.

Magneville, P., 1971. Le flexichoc. Une nouvelle source par implosion pour la prospection sismique en mer. Inst. Fr. Pet., Paris, No. 19116.

Paillet, F. L, and White, J. E., 1982. Acoustic modes of propagation in the borehole and their relationship to rock properties. Geophysics, 47:1215-1228.

Schlich, R., Munschy, M., Boulanger, D., Cantin, B., Coffin, M. F., Durand, J., Humler, E., Li, Z. G., Savary, J., Schaming, M., and Tissot, J. D., 1988. Résultats préliminaires de la campagne océanographique de sismique réflexion multitraces MD 47 dans le domaine sud du plateau de Kerguelen. C.R. Acad. Sci. Paris, Ser. 2, 306:635-642.

Schlich, R., Wise, S. W., et al., 1989. Proc. ODP, Init. Repts., 120: College Station, TX (Ocean Drilling Program).

Sheriff, R. E., 1977. Limitation of resolution of seismic reflections and geologic detail derivable from them. In Payton, C. E. (Ed.), Seismic Stratigraphy: Application to Hydrocarbon Exploration. AAPG Mem., 26:3-14.

Winbow, G. A., 1988. A theoretical study of acoustic $S$-wave and $P$-wave velocity logging with conventional and dipole sources in soft formations. Geophysics, 53:1334-1342.

Date of initial receipt: 7 September 1990

Date of acceptance: 26 February 1991

Ms 120B-121 


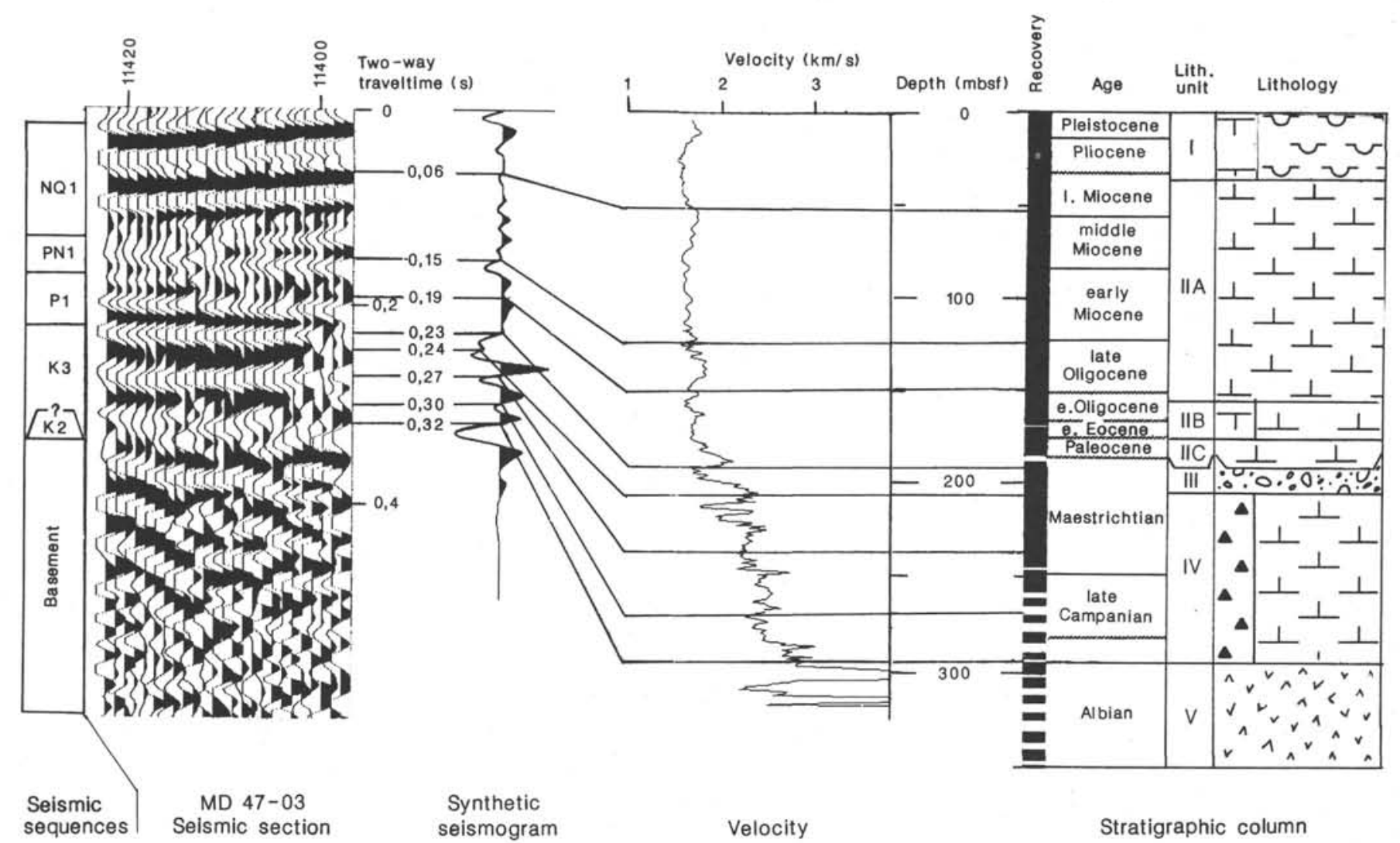

Figure 10. Stratigraphic section at Hole $747 \mathrm{C}$ showing correlation of seismic sequences, MCS Profile MD47-03, synthetic seismogram, corrected velocity logs (DT and DTL), and stratigraphic columns.

Table 3. Correlation between seismic sequences, depth, and ages at Site 747.

\begin{tabular}{|c|c|c|c|c|c|}
\hline \multirow[b]{2}{*}{ Sequence } & \multicolumn{2}{|c|}{ Top of sequence } & \multirow[b]{2}{*}{ Upper limit } & \multirow{2}{*}{$\begin{array}{l}\text { Thickness } \\
\text { (m) }\end{array}$} & \multirow[b]{2}{*}{ Age } \\
\hline & (s twt) & (mbsf) & & & \\
\hline NQ1 & 0 & 0 & Bottom of sea & 30 & $\begin{array}{c}\text { Miocene to } \\
\text { Pliocene }\end{array}$ \\
\hline PN1 & 0.15 & 125 & $\begin{array}{l}\text { Velocity contrast } \\
\text { in Subunit IIA }\end{array}$ & & late Oligocene \\
\hline $\mathrm{P} 1$ and $\mathrm{P} 2$ & 0.19 & 150 & $\begin{array}{l}\text { Top of Subunit } \\
\text { IIB }\end{array}$ & & $\begin{array}{l}\text { Danian to early } \\
\text { Oligocene }\end{array}$ \\
\hline $\mathrm{K} 3$ and $\mathrm{K} 2$ & 0.23 & 190 & Into Unit III & 107 & $\begin{array}{l}\text { Santonian to } \\
\text { Maestrichtian }\end{array}$ \\
\hline Basement & 0.32 & 297 & $\begin{array}{l}\text { Sediment/basalt } \\
\text { contact }\end{array}$ & & $\begin{array}{l}\text { Albian (110 } \\
\text { Ma) }\end{array}$ \\
\hline
\end{tabular}

